\title{
TREN CURAH HUJAN BERBASIS DATA SINOPTIK BMKG DAN REANALISIS MERRA-2 NASA DI PROVINSI SULAWESI TENGAH
}

\section{Trend of Rainfall Based on BMKG Observation Data and MERRA-2 NASA Reanalysis in Central of Sulawesi Province}

\author{
Solih Alfiandy ${ }^{1)^{*}}$, Donaldi Sukma Permana ${ }^{1)}$ \\ ${ }^{1)}$ Stasiun Pemantau Atmosfer Global Lore Lindu Bariri - Badan Meteorologi Klimatologi dan Geofisika, \\ Jl. Abd Rahman Saleh, Bandar Udara Mutiara Sis Al Jufri Palu 94111 \\ *E-mail: solih.alfiandy@bmkg.go.id
}

\begin{abstract}
Intisari
Perubahan iklim dapat mempengaruhi perubahan pola dan intensitas curah hujan. Kajian iklim di Provinsi Sulawesi Tengah sangat penting dilakukan sebagai bahan pertimbangan dalam pengambilan kebijakan di bidang pertanian dan sektor lainnya. Penelitian ini bertujuan untuk mengetahui tren perubahan total curah hujan dan kejadian hujan ekstrem di Provinsi Sulawesi Tengah berdasarkan data dari stasiun sinoptik BMKG dan model reanalisis The Modern-Era Retrospective Analysis for Research and Applications Version 2 dari The National Aeronautics and Space Administration (MERRA-2 NASA) periode 1980-2017. Hasil menunjukkan bahwa kedua data memiliki kemiripan pola musim hujan dan hubungan korelasi positif yang signifikan dengan nilai koefisien determinasi $\left(R^{2}\right)$ sebesar 0,59-0,78 kecuali kota Palu dengan $R^{2}=0,14$. Hal ini menunjukkan bahwa data MERRA-2 berpotensi untuk mengisi data kosong yang terdapat pada stasiun sinoptik BMKG di masa lalu. Selain itu, kedua data menunjukkan tren peningkatan total curah hujan, tren penurunan jumlah hari hujan $<5 \mathrm{~mm} / \mathrm{hari}$, dan tren peningkatan jumlah hari hujan $>50 \mathrm{~mm} / \mathrm{hari}$ (ekstrem) per tahun. Tren peningkatan total hujan tahunan berkisar antara 4,68-52,40 $\mathrm{mm} /$ tahun dengan tren tertinggi terjadi di Kabupaten Poso, sebagian Kabupaten Sigi, Tojo UnaUna, Morowali Utara dan Morowali. Sedangkan tren terendah terjadi di Kabupaten Banggai, Banggai Kepulauan dan Banggai Laut. Tren peningkatan curah hujan bulanan tertinggi terjadi pada bulan April di Poso (4,8 mm/tahun), bulan Januari di Toli-Toli (3,6 mm/tahun) dan bulan Juni di wilayah Luwuk Banggai (2,8 mm/tahun) serta Palu (4,1 mm/tahun). Informasi ini dapat digunakan sebagai bahan pertimbangan dalam kebijakan terkait adaptasi dan mitigasi perubahan iklim di Provinsi Sulawesi Tengah.
\end{abstract}

Kata Kunci: Analisis Tren, Curah Hujan, MERRA-2 NASA, Hujan Ekstrem, Provinsi Sulawesi Tengah

\begin{abstract}
Climate change can affect changes in rainfall patterns and intensity. The study of climate change in Central Sulawesi Province is significant for policymaking in agriculture and other sectors. This study aims to determine trends of rainfall changes and extreme events in the Province of Central Sulawesi based on BMKG data and reanalysis model of The Modern-Era Retrospective Analysis for Research and Applications Version 2 from The National Aeronautics and Space Administration (MERRA-2 NASA) in the period of 1980-2017. Both rainfall data have a similar rainfall seasonality pattern and a significant positive correlation with a determination coefficient (R2) of 0.59-0.78 except for Palu city with $R 2=0.14$. The result shows that MERRA-2 data can fill the gap contained in the past BMKG observation data. Both data show an increasing trend of total rainfall, a decreasing trend of some rainy days with $<5 \mathrm{~mm} /$ days, and a rising trend of several rainy days with $>50 \mathrm{~mm} /$ days (extremes) annually. The annual total rainfall trend increased by 4.68-52.40 $\mathrm{mm} /$ year, with the highest movement was observed in Poso and part of Sigi, Tojo Una-Una, Morowali Utara, and Morowali districts. In contrast, the lowest trend was observed in Banggai, Banggai Kepulauan, and Banggai Laut districts. The highest increasing trend in monthly rainfall occurred in April in Poso (4.8 mm/year), January in Toli-Toli (3.6 mm/year), and June in Luwuk Banggai (2.8 mm/year) and Palu (4.1 mm/year). This information can be used to consider climate change adaptation and mitigation policies in Central Sulawesi Province.
\end{abstract}

Keywords : Trend Analysis, Rainfall, MERRA-2 NASA, Rainfall Extremes, Central of Sulawesi Province 


\section{PENDAHULUAN}

Perubahan kondisi iklim sangat erat kaitannya dengan perubahan pola dan intensitas curah hujan yang akan berdampak pada perubahan musim (Fuentes-Franco et al., 2015; Mufti et al., 2017; Setiawan, 2012). Berdasarkan penelitian dan kajian yang dilakukan oleh para ahli sebelumnya, perubahan intensitas dan pola curah hujan akan mempengaruhi banyak sektor di antaranya sektor pertanian dan ekonomi sosial serta lingkungan (Apriana et al., 2016; Hidayati \& Suryanto, 2015; Hosang et al., 2012; Sudarma \& As-syakur, 2018). Oleh karena itu, perlu dilakukan studi dan kajian tentang perubahan iklim dalam konteks perubahan pola atau laju pertumbuhan tren curah hujan untuk mengetahui kondisi terkini yang terjadi pada suatu wilayah. Hal ini sangat penting dan berpengaruh terhadap mitigasi dan adaptasi yang akan dilakukan terhadap perubahan tersebut. Untuk dapat melihat perubahan pola curah hujan yang terjadi pada suatu wilayah, diperlukan analisis statistik berupa analisis tren agar dapat melihat perubahan intensitas curah hujan berdasarkan data observasi.

Berdasarkan analisis tren hari hujan yang dilakukan Badan Meteorologi Klimatologi dan Geofisika (BMKG), diketahui bahwa secara umum hari hujan di Indonesia memiliki tren positif walaupun di beberapa wilayah seperti Pulau Jawa bernilai negatif dengan besaran yang bervariasi (https://www.bmkg.go.id/iklim/?p =tren-curah-hujan). Provinsi Sulawesi Tengah merupakan salah satu Provinsi yang mengandalkan sektor pertanian sebagai prioritas utama dalam produksi. Oleh karena itu, kajian perubahan iklim, khususnya curah hujan di Sulawesi Tengah sangat penting sebagai bahan pertimbangan dalam mengambil kebijakan di bidang pertanian dan sektor lainnya (Santoso, 2015; Surmaini et al., 2015). Saat ini, BMKG mempunyai 4 stasiun pengamatan curah hujan yang memiliki panjang data lebih dari 20 tahun. Selain itu, data curah hujan juga dapat diperoleh secara spasial dari berbagai data reanalisis (data analisis gabungan antara data model dan observasi global seperti satelit dan data observasi lainnya). Salah satu data reanalisis yang biasa digunakan adalah The Modern-Era Retrospective Analysis for Research and Applications Version 2 (MERRA-2) dari The National Aeronautics and Space Administration (NASA), Amerika Serikat (Gelaro et al., 2017). Data MERRA-2 NASA dapat menjadi pembanding dari data observasi BMKG dalam mengidentifikasi perubahan tren curah hujan. Seperti penelitian sebelumnya yang memvalidasi data satelit dengan data observasi stasiun (Dasanto et al., 2014; Fitria, 2016; Syaifullah, 2014). Pada penelitian ini dilakukan validasi data MERRA-2 NASA dengan data stasiun BMKG.
Jika hasil validasi cukup baik, maka data MERRA-2 NASA berpotensi untuk mengisi data kosong pada data pengamatan BMKG di masa lalu.

Penelitian ini bertujuan untuk mengetahui perubahan tren curah hujan dan informasi kejadian iklim ekstrem tahunan di Provinsi Sulawesi Tengah berdasarkan data observasi di 4 stasiun sinoptik BMKG dan data reanalisis MERRA-2 NASA periode tahun 1980-2017. Selain itu, perubahan tren curah hujan bulanan, frekuensi kejadian hujan ekstrem pada periode tersebut juga diidentifikasi untuk melihat potensi terjadinya iklim ekstrem di masa mendatang.

\section{METODE}

BMKG memiliki 4 stasiun pengamatan sinoptik yaitu Stasiun Meteorologi (Stamet) Syukuran Aminuddin Luwuk Banggai, Stamet Kasiguncu Poso, Stamet Sultan Bantilan Toli-Toli dan Stamet Mutiara Sis Aljufri Palu. Metadata stasiun tersebut ditampilkan pada Tabel 1 dan Gambar 1. Data reanalisis MERRA-2 merupakan data grid dengan resolusi spasial sebesar $0,5^{\circ}$ untuk lintang dan $0,625^{\circ}$ untuk bujur dengan jumlah 42 grid untuk Provinsi Sulawesi Tengah (Gambar 1). Pada studi ini, parameter data MERRA-2 yang digunakan adalah total curah hujan di daratan (total precipitation land).

Langkah pertama yang dilakukan adalah melakukan perbandingan data curah hujan stasiun sinoptik BMKG dengan data grid MERRA-2 terdekat dengan titik stasiun sinoptik BMKG. Dalam kajian ini, data MERRA-2 yang digunakan yaitu grid 232373 yang dibandingkan dengan Stamet Luwuk, data grid 232977 yang dibandingkan dengan Stamet Poso, data grid 229942 yang dibandingkan dengan Stamet ToliToli dan data grid 232369 yang dibandingkan dengan Stamet Palu. Perbandingan dilakukan dengan menggunakan analisis regresi linier berganda dengan menghitung nilai koefisien determinasi $\left(\mathrm{R}^{2}\right)$ dan nilai bias/error (Root Mean Square Error-RMSE), kemudian pola musim hujan dari kedua data tersebut dibandingkan untuk menunjukkan kemiripan data MERRA-2 dengan data observasi BMKG. Tahap berikutnya adalah melakukan analisis tren perubahan total curah hujan tahunan dan rata-rata curah hujan per bulan pada tiap grid data MERRA-2 yang mewakili tiap stasiun BMKG periode 1980-2017. Pada tahap akhir, tren jumlah hari per tahun untuk hujan $<5 \mathrm{~mm} /$ hari dan $>50 \mathrm{~mm} /$ hari dianalisis untuk memperoleh informasi potensi kejadian iklim ekstrem di masa mendatang pada masing-masing kabupaten di wilayah Provinsi Sulawesi Tengah. Pengolahan data dan visualisasi gambar dilakukan dengan menggunakan software Microsoft Excel, QGIS, dan Python. 
Tabel 1. Metadata Stasiun Meteorologi di Sulawesi Tengah

\begin{tabular}{|c|c|c|c|c|c|}
\hline \multirow{2}{*}{$\begin{array}{l}\text { WMO. } \\
\text { ID }\end{array}$} & \multirow{2}{*}{ Nama Stasiun } & \multicolumn{2}{|c|}{ Koordinat $\left({ }^{\circ}\right)$} & \multirow{2}{*}{$\begin{array}{l}\text { Elevasi } \\
\text { (mdpl) }\end{array}$} & \multirow{2}{*}{$\begin{array}{l}\text { Periode Data } \\
\text { Curah Hujan }\end{array}$} \\
\hline & & Lintang & Bujur & & \\
\hline 97072 & Mutiar & $-0,92$ & 119,90 & 84 & $1980-2017$ \\
\hline 97096 & Kas & $-1,42$ & 120,65 & 12,02 & 1998-2017 \\
\hline 97028 & Sultan Bantilan, Toli - Toli & 1,12 & 120,80 & 247,63 & 1982-2017 \\
\hline 97086 & $\begin{array}{c}\text { Syukuran Aminuddin Amir Luwuk, } \\
\text { Banggai }\end{array}$ & $-1,04$ & 122,77 & 33 & 1980-2017 \\
\hline
\end{tabular}

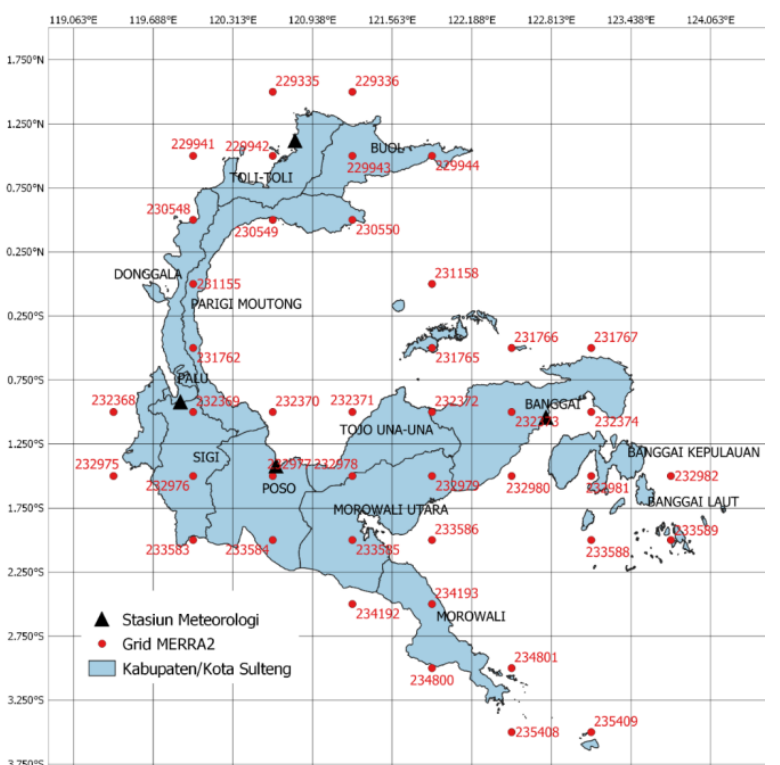

Gambar 1. Peta sebaran Stasiun Meteorologi sinoptik dan grid data reanalisis MERRA-2 NASA di Sulawesi Tengah.

\section{HASIL DAN PEMBAHASAN}

\subsection{Stasiun Meteorologi Syukuran Aminuddin Luwuk Banggai}

Secara umum, curah hujan observasi Stasiun Meteorologi Luwuk Banggai dan curah hujan reanalisis MERRA-2 NASA memiliki pola yang relatif sama pada periode data 1980-2017. Walaupun terdapat periode dimana intensitas curah hujan dan data reanalisis MERRA-2 NASA sedikit lebih tinggi dibandingkan curah hujan observasi di Stasiun Meteorologi Luwuk Banggai (Gambar 2a). Hal ini ditunjukkan dengan adanya hubungan linier dan korelasi positif antara data curah hujan observasi Stasiun Meteorologi Luwuk Banggai dengan data curah hujan reanalisis MERRA-2 NASA pada grid 232373. Hubungan positif ini memiliki makna bahwa jika nilai curah hujan observasi mengalami peningkatan maka nilai curah hujan pada data reanalisis juga meningkat. Hasil analisis scatterplot mendukung adanya hubungan kuat antara data curah hujan observasi di Stasiun Meteorologi Syukuran Aminuddin Luwuk Banggai dan data MERRA-2 NASA yang memiliki nilai koefisien determinasi $\left(R^{2}\right)$ sebesar 0,6796 $(p<$ $0,05)$ dan nilai RMSE sebesar 47,11 $\mathrm{mm}$ (Gambar 2b).
Gambar 2c menunjukkan bahwa rata-rata curah hujan bulanan antara observasi dan data reanalisis memiliki pola yang sama, meskipun intensitas curah hujan reanalisis sedikit lebih tinggi dibandingkan dengan observasi. Pada bulan Juli intensitas curah hujan observasi lebih tinggi dibandingkan dengan reanalisis, sedangkan pada bulan Agustus intensitas keduanya sama. Gambar 2c menunjukkan pola hujan anti-monsunal di Luwuk (Aldrian \& Susanto, 2003). Hal ini juga didukung oleh data hasil pengamatan alat pemantau cuaca otomatis di Luwuk (Alfiandy et al., 2020a). Gambar 2d menunjukkan bahwa laju pertumbuhan total curah hujan tahunan di wilayah Stasiun Meteorologi Syukuran Aminuddin Luwuk Banggai mengalami peningkatan sebesar 11,96 $\mathrm{mm}$ /tahun. Sedangkan, tren rata-rata curah hujan bulanan mengalami pertumbuhan sebesar 0,12,8 $\mathrm{mm} /$ tahun (Gambar 2e). Tren curah hujan tertinggi terjadi pada bulan Juni dan terendah terjadi pada bulan Maret dan Mei.

Gambar $2 f$ dan $2 g$ menunjukkan jumlah hari per tahun (frekuensi) dengan intensitas hujan $<5 \mathrm{~mm} /$ hari (gerimis) dan $>50 \mathrm{~mm} /$ hari (ekstrem) data observasi, secara umum, lebih besar dari data MERRA-2 NASA pada periode data tersedia. Analisis tren menunjukkan bahwa pada data observasi terdapat penurunan jumlah hari hujan gerimis sebesar 0,3354 per tahun dan terjadi peningkatan jumlah hari hujan kategori ekstrem sebesar 0,051 per tahun. Sedangkan pada data MERRA2, laju penurunan jumlah hari hujan gerimis lebih cepat dan laju peningkatan jumlah hari hujan ekstrem lebih lambat dari pada data observasi.

Adanya tren peningkatan total curah hujan dan jumlah kejadian hujan ekstrem di wilayah ini sejalan dengan hasil penelitian sebelumnya yang menyatakan bahwa terdapat kecenderungan kondisi yang lebih basah di wilayah bagian utara Indonesia (Supari et al., 2017).

\subsection{Stasiun Meteorologi Kasiguncu Poso}

Gambar 3a menunjukkan intensitas curah hujan observasi di Stasiun Meteorologi Kasiguncu Poso dan reanalisis MERRA-2 NASA memiliki pola yang sama pada periode 19982017. Hasil ini didukung oleh kajian sebelumnya (Syaifullah, 2014) yang mengkaji tentang validasi data satelit TRMM JAXA (GSMap_NRT) 
OBS vs. MERRA-2 (Grid : 232373)

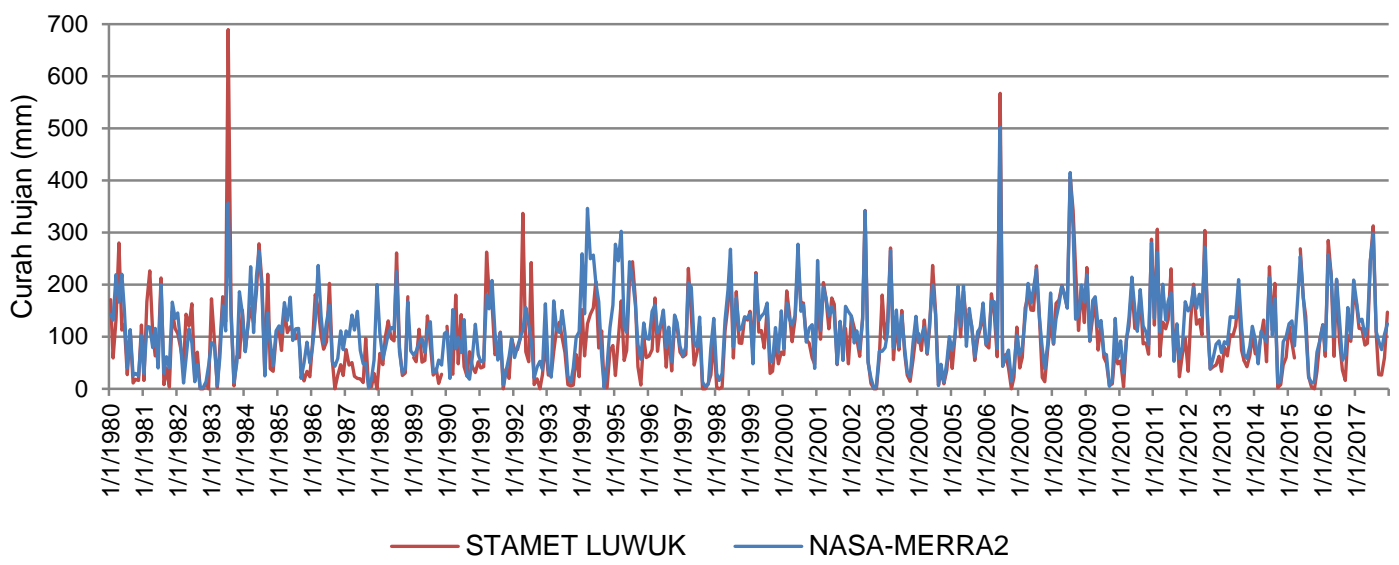

(a)

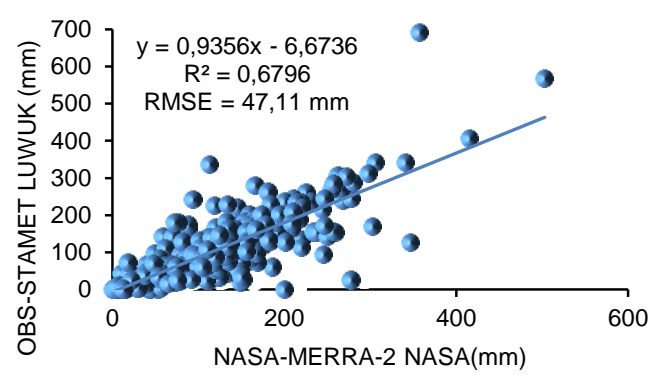

(b)

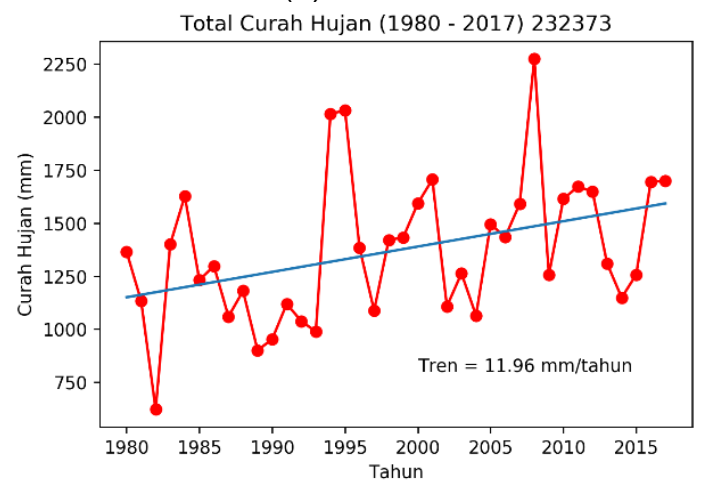

(d)

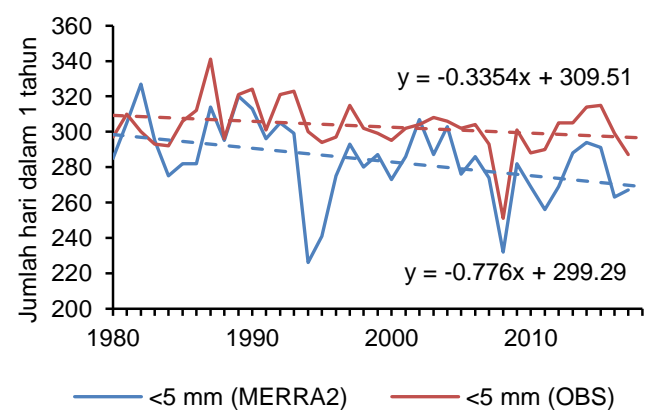

(f)

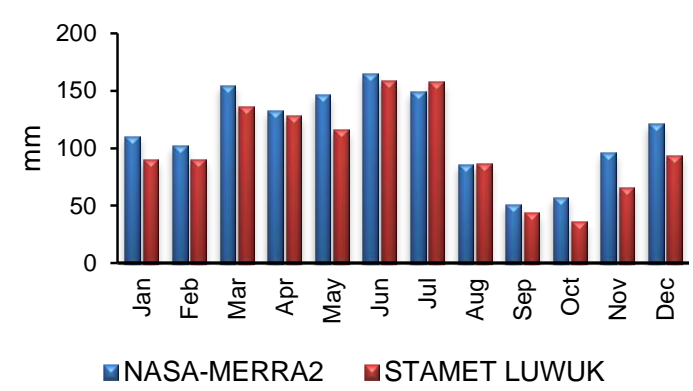

(c)

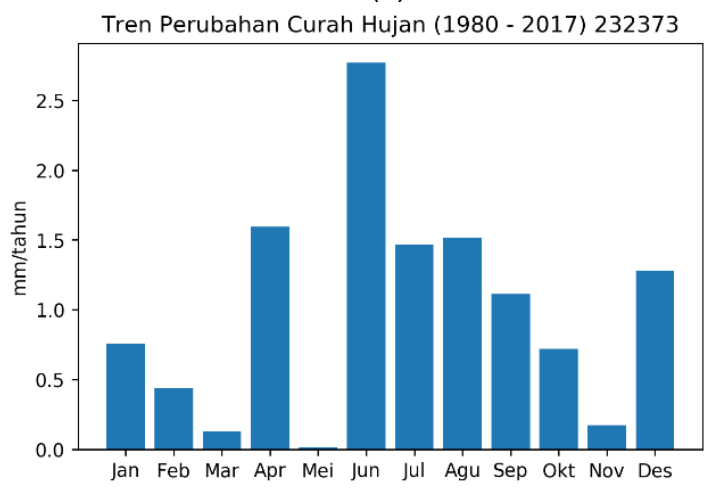

(e)

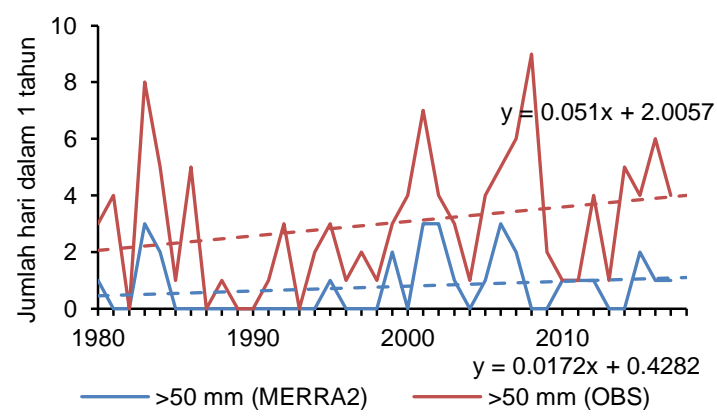

(g)

Gambar 2. (a) Perbandingan curah hujan observasi di Stasiun Meteorologi Syukuran Aminuddin Luwuk Banggai dan reanalisis MERRA-2 NASA pada grid 232373 periode 1980-2017, (b) scatterplot data curah hujan observasi dan reanalisis, (c) perbandingan rata-rata curah hujan bulanan antara observasi dan reanalisis, (d) tren total curah hujan tahunan MERRA-2, (e) tren rata-rata curah hujan bulanan MERRA-2, tren jumlah hari dalam 1 tahun dengan intensitas (f) $<5 \mathrm{~mm} /$ hari dan $(\mathrm{g})>50 \mathrm{~mm} / \mathrm{hari}$. 
terhadap data observasi permukaan dengan hasil bahwa data satelit memiliki pola yang sama dengan data curah hujan observasi (aktual) meskipun nilainya cenderung lebih rendah. Gambar 3b menunjukkan adanya hubungan linier dan korelasi positif antara curah hujan Stasiun Meteorologi Kasiguncu Poso dan curah hujan reanalisis MERRA-2 NASA pada grid 232977. Hubungan positif ini memiliki makna jika intensitas curah hujan observasi mengalami peningkatan maka curah hujan data reanalisis juga meningkat. Dari hasil analisis scatterplot diperoleh nilai $R^{2}$ sebesar $0,5913(p<0,05)$ dan RMSE sebesar 69,02 mm antara curah hujan observasi dari Stasiun Meteorologi Kasiguncu Poso dan curah hujan pada grid 232977 data reanalisis MERRA-2 NASA.

Gambar 3c menunjukkan rata-rata curah hujan bulanan antara data observasi dan reanalisis memiliki pola yang sama dengan puncak hujan terjadi pada bulan April dan Desember. Gambar 3d menunjukkan bahwa laju pertumbuhan total curah hujan tahunan di wilayah Stasiun Meteorologi Kasiguncu Poso mengalami peningkatan sebesar 38,25 $\mathrm{mm} /$ tahun. Sedangkan, tren rata-rata curah hujan bulanan mengalami pertumbuhan sebesar 0,94,8 mm/tahun (Gambar 3e). Tren curah hujan tertinggi terjadi pada bulan April dan terendah terjadi pada bulan Januari.

Data observasi menunjukkan bahwa terdapat tren penurunan jumlah hari hujan gerimis sebesar 1,5925 per tahun dan terjadi peningkatan jumlah hari hujan kategori ekstrem sebesar 0,1722 per tahun pada periode 19982017 (Gambar 3f dan 3g). Sedangkan pada data MERRA-2 NASA, baik laju penurunan jumlah hari hujan gerimis maupun laju peningkatan jumlah hari hujan ekstrem lebih lambat dari pada data observasi

\subsection{Stasiun Meteorologi Sultan Bantilan Toli-Toli}

Seperti halnya di Luwuk Banggai dan Poso, intensitas curah hujan observasi di Stasiun Meteorologi Sultan Bantilan Toli-Toli dan curah hujan reanalisis MERRA-2 NASA memiliki pola yang sama pada periode 1982-2017 (Gambar 4a). Intensitas curah hujan reanalisis MERRA-2 NASA sedikit lebih rendah dari (underestimate) curah hujan observasi Stasiun Meteorologi Sultan Bantilan Toli-Toli. Gambar 4b menunjukkan bahwa terdapat hubungan yang linier dan positif antara data curah hujan Stasiun Meteorologi Sultan Bantilan Toli-Toli dan curah hujan reanalisis MERRA-2 NASA pada grid 229942. Dari hasil analisis scatterplot didapatkan bahwa antara curah hujan reanalisis MERRA-2 NASA dengan curah hujan observasi memiliki nilai $R^{2}$ sebesar $0,779(p<0,05)$ dan RMSE sebesar $58,58 \mathrm{~mm}$ yang menunjukkan kemiripan kedua data. Hal ini mengindikasikan bahwa data reanalisis MERRA-2 NASA berpotensi untuk dapat digunakan mengisi data kosong pada data observasi masa lalu di Stasiun Meteorologi Sultan Bantikan Toli-Toli seperti pada tahun 1985-1993 dan 2010 (Gambar 4a).

Gambar 4c menunjukkan rata-rata curah hujan bulanan antara data observasi dan reanalisis memiliki pola yang sama dengan puncak hujan terjadi pada bulan Juni-Juli dan Desember-Januari. Hal ini sejalan dengan penelitian sebelumnya yang menggunakan data pengamatan dari alat pemantau cuaca otomatis (Alfiandy et al., 2020a). Gambar 4d menunjukkan tren total curah hujan tahunan meningkat sebesar 23,22 $\mathrm{mm} / \mathrm{tahun}$ di wilayah Stasiun Meteorologi Sultan Bantilan Toli-Toli. Sedangkan, tren rata-rata curah hujan bulanan mengalami peningkatan sebesar 0,2-3,8 mm/tahun (Gambar 4e). Tren curah hujan tertinggi terjadi pada bulan Januari dan Desember sedangkan terendah terjadi pada bulan April dan September.

Data observasi menunjukkan bahwa terdapat tren penurunan jumlah hari hujan gerimis sebesar 0,2957 per tahun dan terjadi peningkatan jumlah hari hujan kategori ekstrem sebesar 0,1507 per tahun pada periode 19822017 (Gambar 4f dan 4g). Sedangkan pada data MERRA-2 NASA, laju penurunan jumlah hari hujan gerimis lebih cepat dari pada data observasi, sedangkan laju peningkatan jumlah hari hujan ekstrem lebih lambat.

\subsection{Stasiun Meteorologi Mutiara Sis Aljufri Palu}

Perbandingan intensitas curah hujan observasi Stasiun Meteorologi Mutiara Palu dan curah hujan reanalisis MERRA-2 NASA ditunjukkan pada Gambar 5a. Secara umum, kedua data memiliki pola yang sama pada periode 1980-2017, kecuali pada periode 19931996 dimana data reanalisis MERRA-2 NASA jauh lebih tinggi (overestimate) dari curah hujan observasi. Pada umumnya, setelah tahun 1996, data MERRA-2 NASA juga overestimate dari data observasi. Curah hujan reanalisis dari MERRA-2 NASA memiliki intensitas lebih tinggi dari curah hujan observasi dari Stasiun Meteorologi Mutiara Sis Aljufri Palu. Hal ini dapat disebabkan karena kota Palu memiliki pola hujan dengan tipe lokal dan kering akibat berada di antara dua pegunungan (Alfiandy et al., 2020) dan resolusi spasial MERRA-2 NASA yang cukup rendah sehingga tidak dapat menangkap pola hujan bertipe lokal dengan topografi yang kompleks. Walaupun demikian, masih terdapat hubungan yang linier dan positif antara data observasi dan curah hujan reanalisis MERRA-2 NASA pada grid 232369 (Gambar 5b). Analisis scatterplot menunjukkan bahwa nilai $R^{2}$ sebesar $0,1441(p<0,05)$ dan RMSE sebesar 94,14 mm antara data observasi dan reanalisis MERRA-2 NASA. Nilai $R^{2}$ di kota Palu merupakan nilai 
paling rendah dibandingkan pada Kabupaten

Banggai, Poso dan Toli-Toli.

OBS vs. MERRA-2 (Grid : 232977)

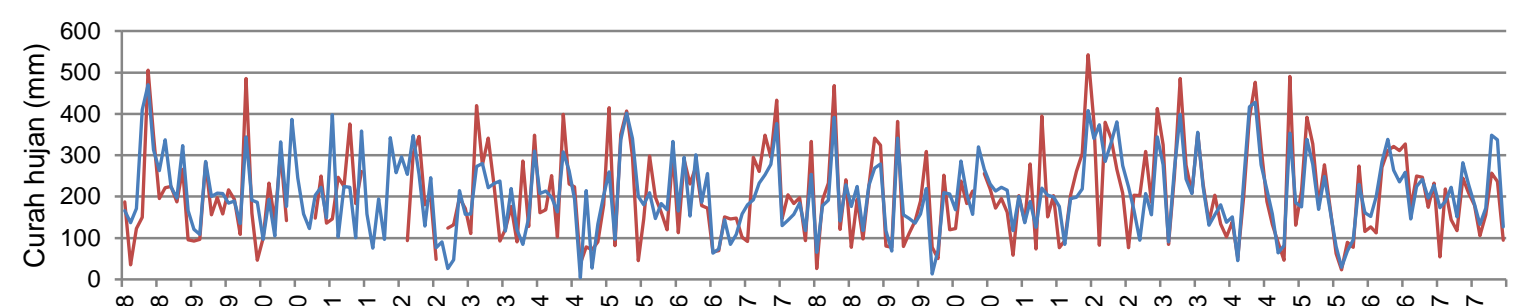

o

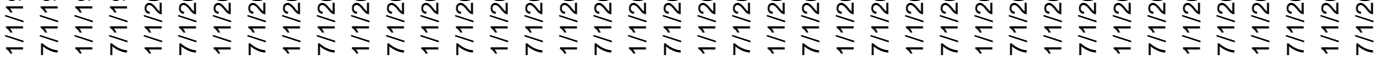

— OBS-STAMET POSO

- NASA-MERRA2

(a)

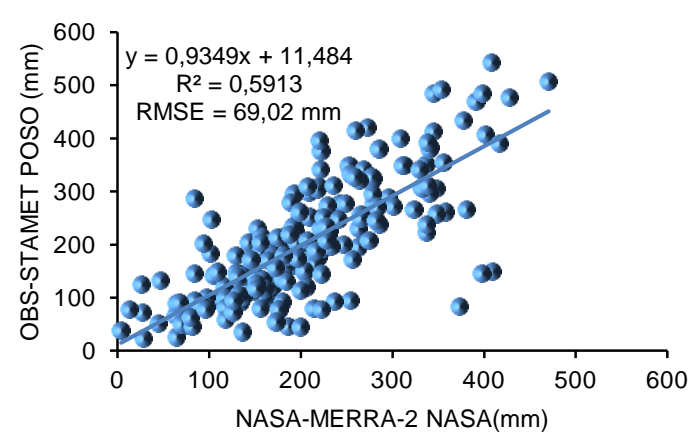

(b)

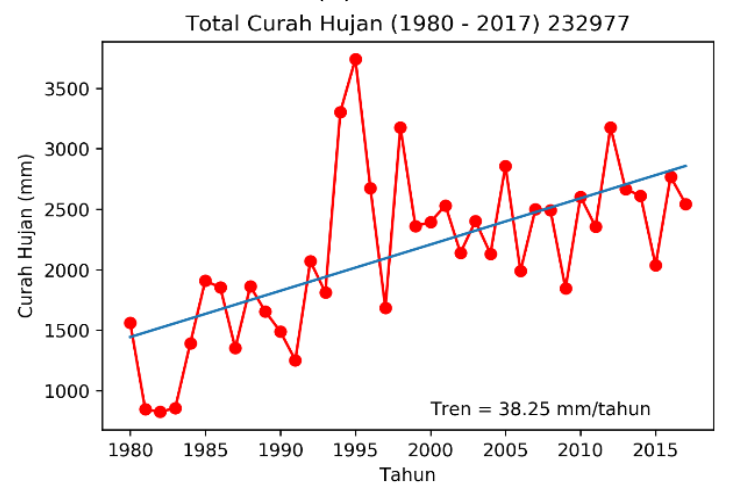

(d)

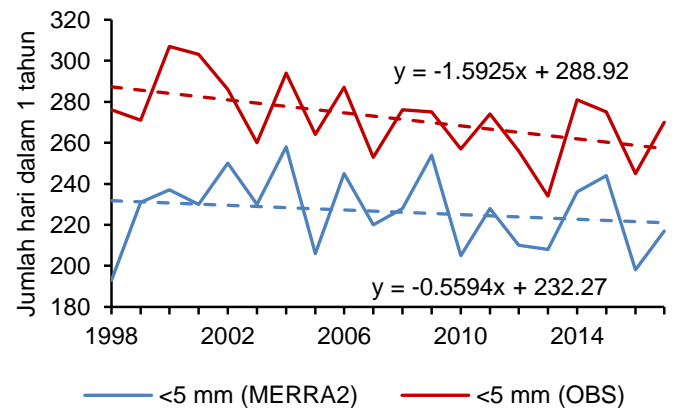

(f)

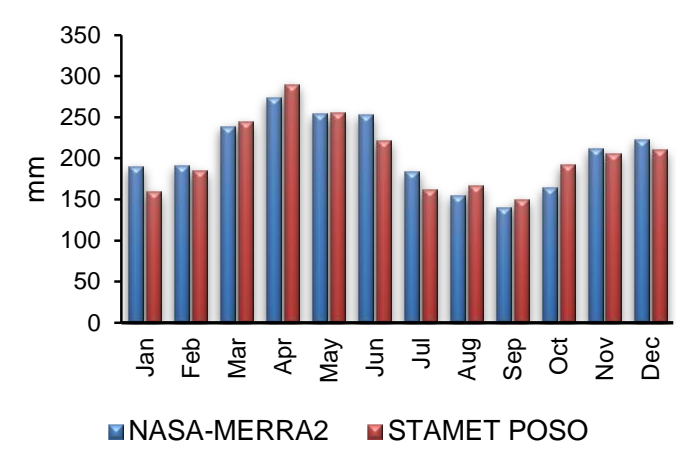

(c)

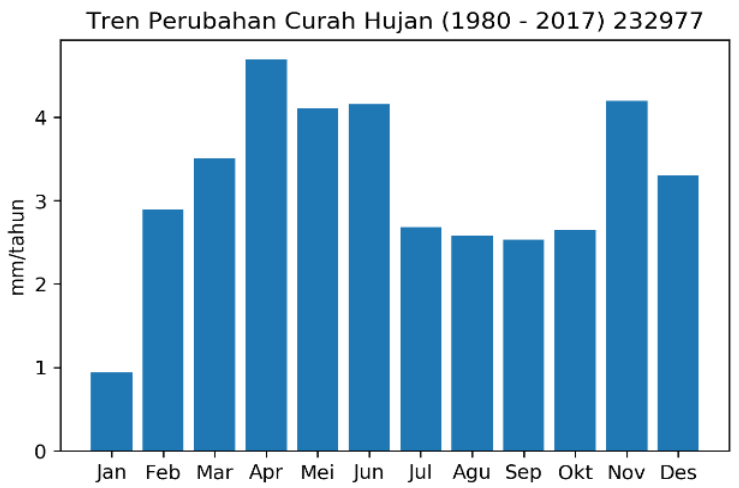

(e)

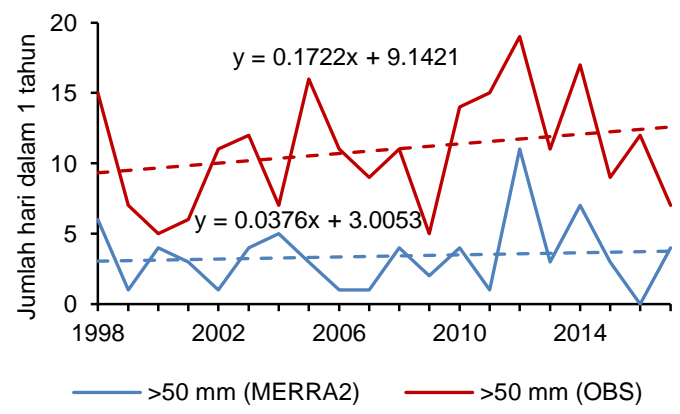

(g)

Gambar 3. (a) Perbandingan curah hujan observasi di Stasiun Meteorologi Kasiguncu Poso dan reanalisis MERRA-2 NASA pada grid 232977 periode 1998-2017, (b) scatterplot data curah hujan observasi dan reanalisis, (c) perbandingan rata-rata curah hujan bulanan antara observasi dan reanalisis, (d) tren total curah hujan tahunan MERRA-2, (e) tren rata-rata curah hujan bulanan MERRA2 , tren jumlah hari dalam 1 tahun dengan intensitas (f) $<5 \mathrm{~mm} /$ hari dan (g) $>50 \mathrm{~mm} /$ hari. 
OBS vs. MERRA-2 (Grid : 229942)

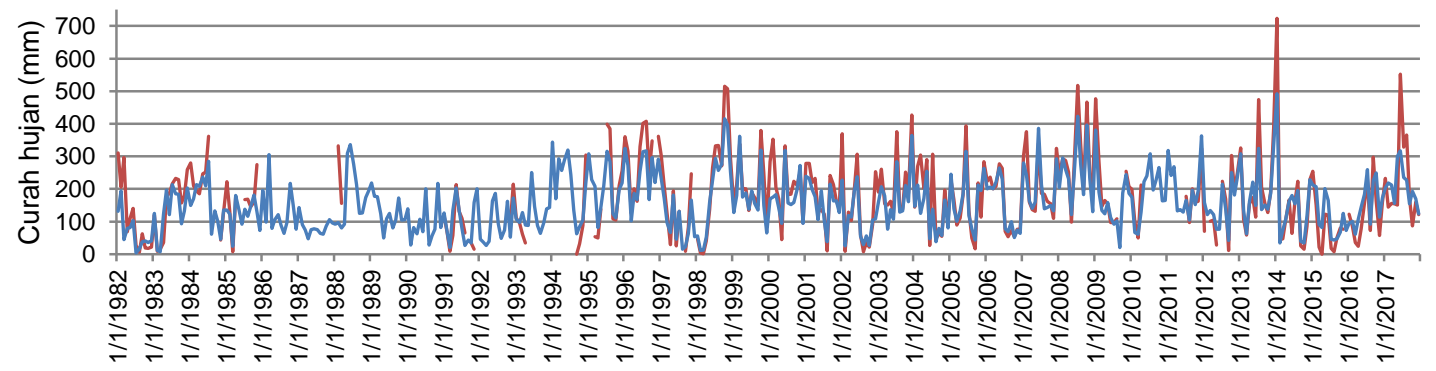

- OBS-STAMET TOLITOLI — NASA-MERRA2

(a)

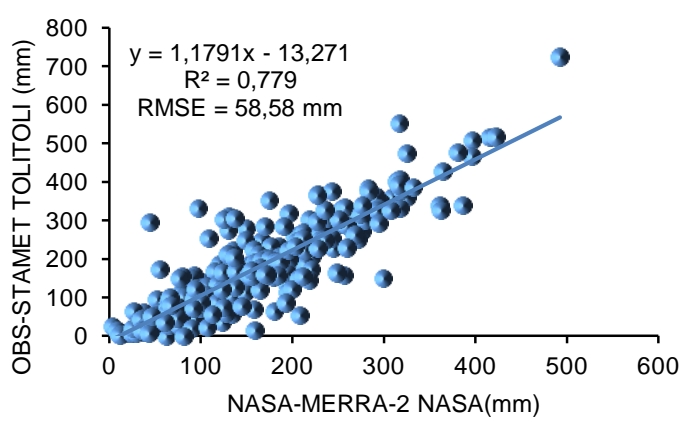

(b)

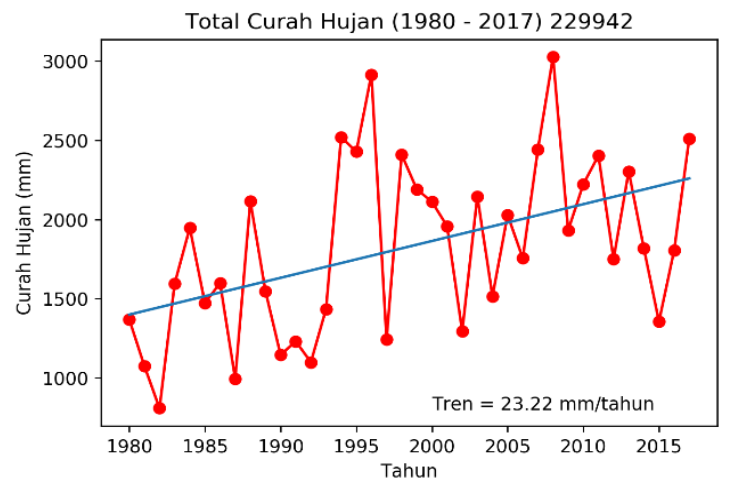

(d)

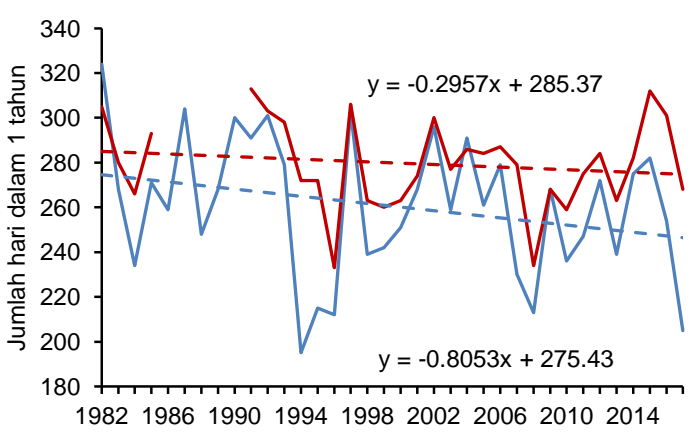

$<5 \mathrm{~mm}$ (MERRA2)

$\longrightarrow<5 \mathrm{~mm}(\mathrm{OBS})$

(f)

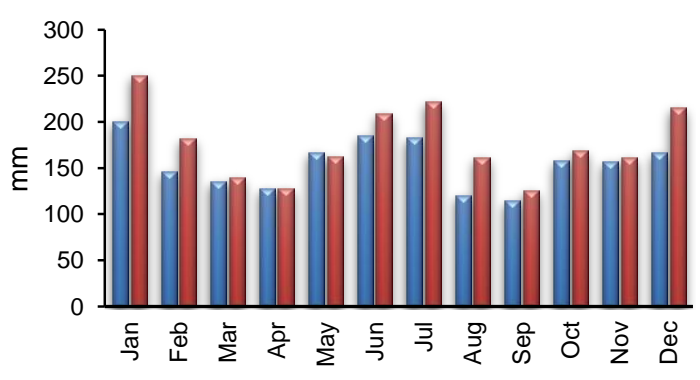

INASA-MERRA2 घSTAMET TOLI-TOLI

(c)

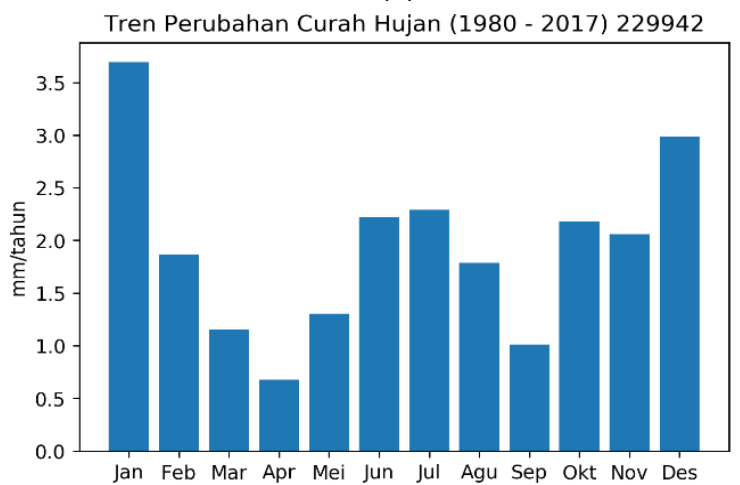

(e)

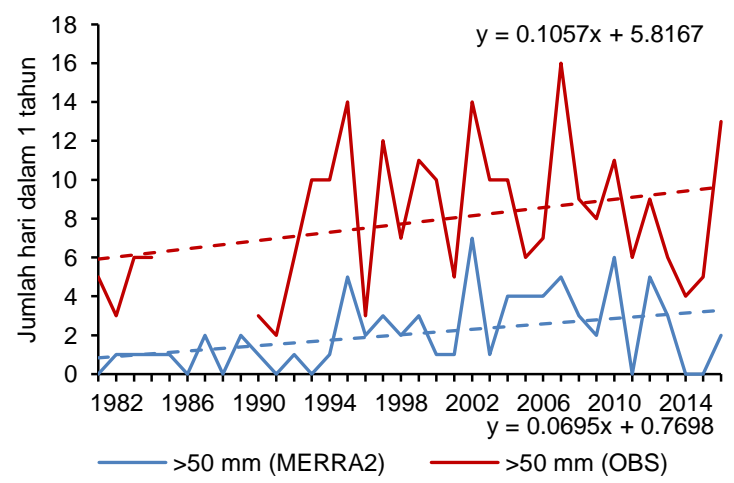

(g)

Gambar 4. (a) Perbandingan curah hujan observasi di Stasiun Meteorologi Sultan Bantilan Toli-Toli dan reanalisis MERRA-2 NASA pada grid 229942 periode 1982-2017, (b) scatterplot data curah hujan observasi dan reanalisis, (c) perbandingan rata-rata curah hujan bulanan antara observasi dan reanalisis,

(d) tren total curah hujan tahunan MERRA-2, (e) tren rata-rata curah hujan bulanan MERRA-2, tren jumlah hari dalam 1 tahun dengan intensitas $(\mathrm{f})<5 \mathrm{~mm} /$ hari dan $(\mathrm{g})>50 \mathrm{~mm} / \mathrm{hari}$. 
OBS vs. MERRA-2 (Grid : 232369)

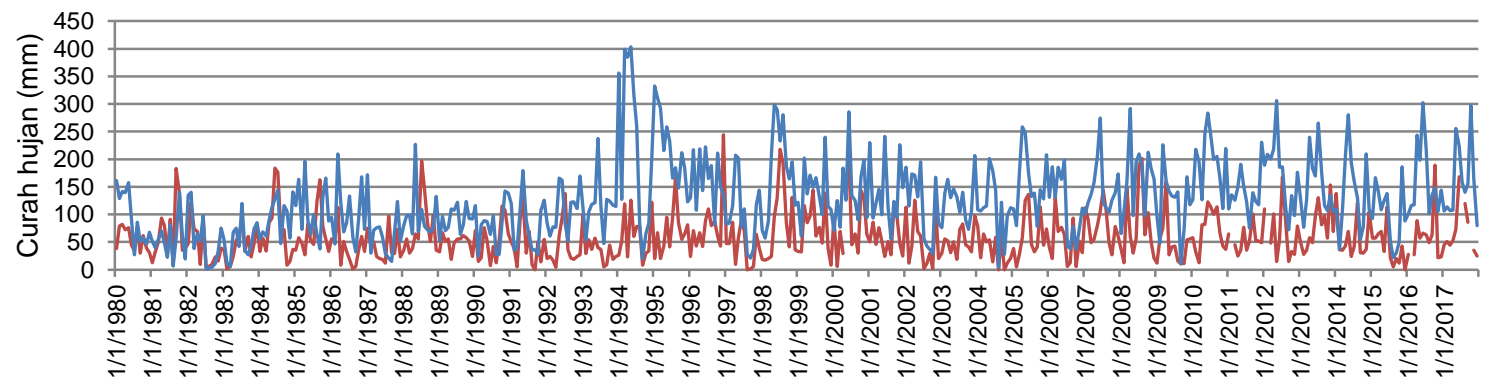

STAMET PALU — NASA-MERRA2

(a)

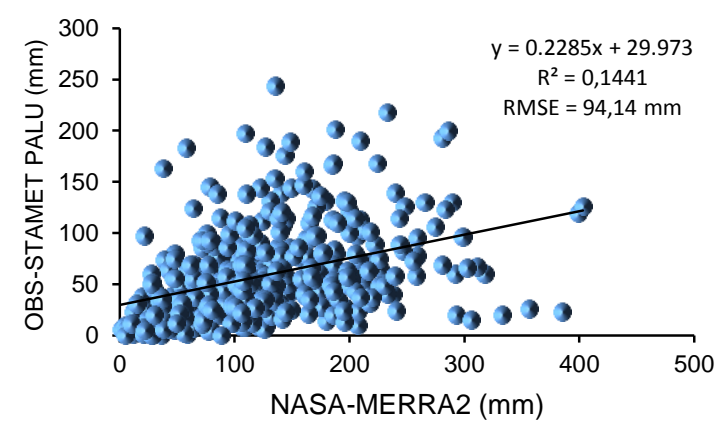

(b)

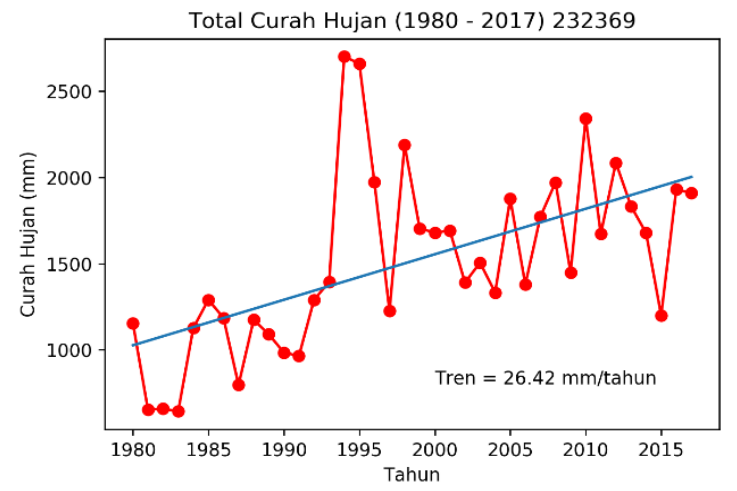

(d)

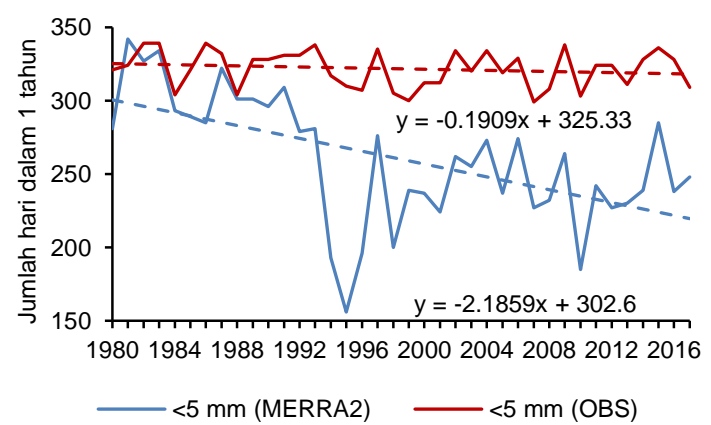

(f)

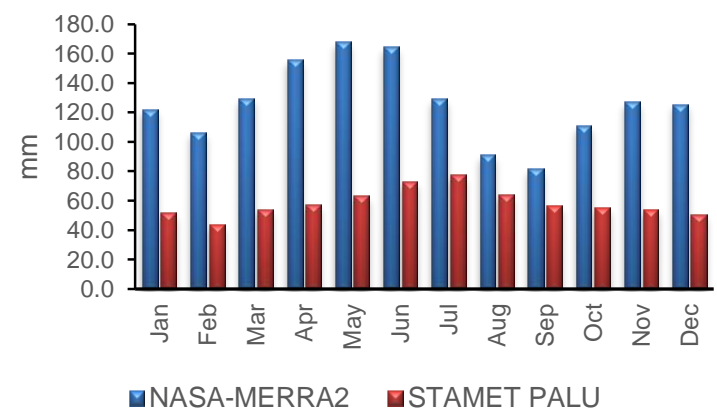

(c)

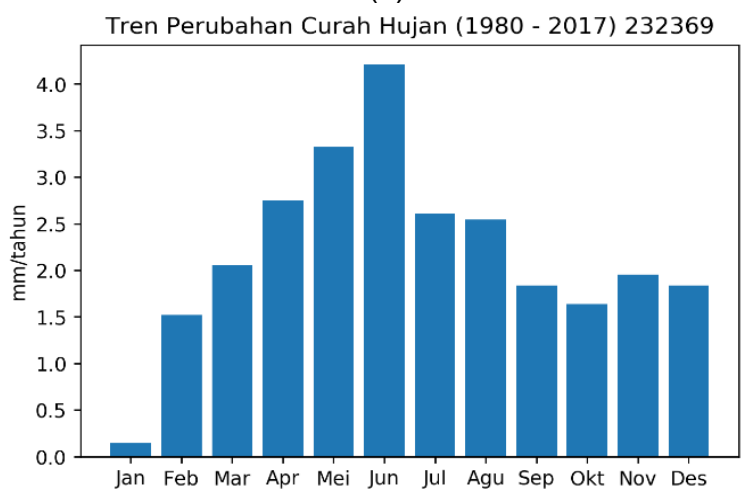

(e)

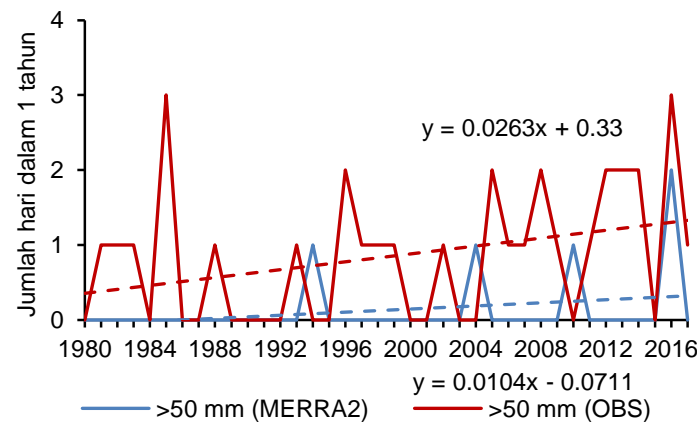

(g)

Gambar 5. (a) Perbandingan curah hujan observasi di Stasiun Meteorologi Mutiara Palu dan reanalisis MERRA-2 NASA pada grid 231762 periode 1980-2017, (b) scatterplot data curah hujan observasi dan reanalisis, (c) perbandingan rata-rata curah hujan bulanan antara observasi dan reanalisis, (d) tren total curah hujan tahunan MERRA-2, (e) tren rata-rata curah hujan bulanan MERRA-2, tren jumlah hari dalam 1 tahun dengan intensitas (f) $<5 \mathrm{~mm} /$ hari dan $(\mathrm{g})>50 \mathrm{~mm} / \mathrm{hari}$. 
paling rendah dibandingkan pada Kabupaten Banggai, Poso dan Toli-Toli.

Gambar 5c menunjukkan rata - rata curah hujan bulanan antara data observasi dan reanalisis yang memiliki pola yang cukup berbeda dengan data reanalisis selalu lebih tinggi (sekitar 20-100 mm/bulan) dari data observasi. Gambar 5d menunjukkan tren total curah hujan tahunan meningkat sebesar $26,42 \mathrm{~mm} /$ tahun di wilayah Stasiun Meteorologi Mutiara Sis Aljufri Palu. Sedangkan, tren rata-rata curah hujan bulanan mengalami peningkatan sebesar $0,1-4,2$ $\mathrm{mm} /$ tahun (Gambar 5e). Tren curah hujan tertinggi terjadi pada bulan Juni dan terendah terjadi pada bulan Januari.

Gambar $5 f$ dan $5 \mathrm{~g}$ menunjukkan bahwa terdapat tren penurunan jumlah hari hujan gerimis sebesar 0,1909 per tahun dan terjadi peningkatan jumlah hari hujan kategori ekstrem sebesar 0,0263 per tahun pada periode 19802017. Sedangkan pada data MERRA-2 NASA, laju penurunan jumlah hari hujan gerimis jauh lebih cepat dari pada data observasi, sedangkan laju peningkatan jumlah hari hujan ekstrem lebih lambat.

\subsection{Tren Spasial Curah Hujan Provinsi Sulawesi Tengah}

Pada bagian 3.1-3.4 telah ditunjukkan bahwa data curah hujan dari grid MERRA-2 NASA dan data observasi curah hujan di Stasiun Meteorologi Luwuk, Poso, Toli - Toli dan Palu berkorelasi positif secara signifikan dengan nilai bias atau RMSE yang cukup baik. Selain itu, kedua data tersebut memiliki pola tren yang sama yaitu kecenderungan peningkatan total curah hujan tahunan pada periode 1980-2017. Akan tetapi, nilai tren perubahan curah hujan hanya tersedia pada 4 lokasi stasiun tersebut.

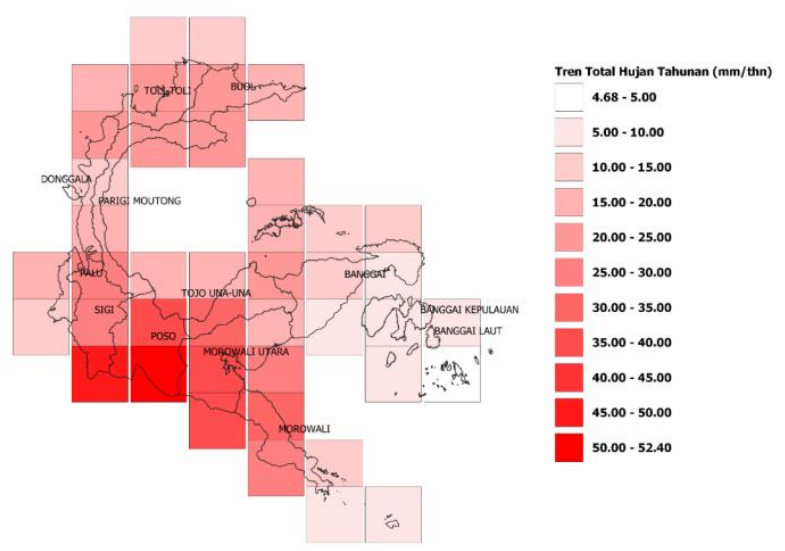

Gambar 6. Pola tren spasial total hujan tahunan berdasarkan grid data MERRA-2 NASA di Provinsi Sulawesi Tengah

Bila diasumsikan bahwa 4 lokasi stasiun tersebut dapat mewakili Provinsi Sulawesi Tengah, maka nilai tren perubahan curah hujan dapat dihitung untuk data grid MERRA-2 NASA lainnya sehingga dapat mencakup seluruh wilayah Provinsi Sulawesi Tengah. Gambar 6 menunjukkan tren spasial perubahan curah hujan tahunan untuk 42 data grid MERRA-2 NASA yang mencakup seluruh wilayah Sulawesi Tengah. Tren peningkatan total hujan tahunan berkisar antara 4,68-52,40 mm/tahun dengan tren tertinggi terjadi pada Kabupaten Poso, sebagian Kabupaten Sigi, Tojo Una-una, Morowali Utara dan Morowali. Sedangkan tren terendah terjadi pada Kabupaten Banggai, Banggai Kepulauan dan Banggai Laut.

\section{KESIMPULAN}

Secara umum, hasil analisis dan pembahasan didapatkan bahwa data curah hujan observasi dan data curah hujan reanalisis MERRA-2 NASA memiliki kemiripan pola. Namun, data curah hujan reanalisis MERRA-2 NASA memiliki intensitas atau nilai yang lebih tinggi dibandingkan dengan data curah hujan observasi pada Stasiun Meteorologi Syukuran Aminuddin Luwuk Banggai, Stasiun Meteorologi Sultan Bantilan Toli-Toli dan Stasiun Meteorologi Mutiara Palu. Meskipun nilai data reanalisis dari MERRA-2 NASA lebih tinggi dibandingkan data observasi, data curah hujan reanalisis dari MERRA-2 NASA berpotensi untuk bisa digunakan dalam mengisi data kosong di masa lalu pada stasiun-stasiun tertentu, seperti pada Stasiun Meteorologi Sultan Bantilan Toli-Toli, tentunya dengan metode tertentu.

Selain itu, hasil penelitian ini menunjukkan tren peningkatan total curah hujan tahunan pada tiap wilayah stasiun berbasiskan data curah hujan sinoptik dan reanalisis MERRA-2 NASA yang mengalami peningkatan sebesar 11,96$38,25 \mathrm{~mm} /$ tahun. Sedangkan tren peningkatan rata-rata curah hujan bulanan sebesar 0,1-4,8 $\mathrm{mm} /$ tahun pada periode tahun 1980-2017. Secara garis besar jumlah hari per tahun (frekuensi) dengan intensitas hujan $<5 \mathrm{~mm} /$ hari (gerimis) dan $>50 \mathrm{~mm} /$ hari (ekstrem) pada data observasi di tiap stasiun lebih besar dari data MERRA-2 NASA. Terdapat juga tren penurunan jumlah hari hujan gerimis dan tren peningkatan jumlah hari hujan ekstrem disetiap tahunnya. Sedangkan pada data MERRA-2 NASA, laju penurunan jumlah hari hujan gerimis lebih cepat dan laju peningkatan jumlah hari hujan ekstrem lebih lambat dari pada data observasi.

Tren peningkatan total hujan tahunan berkisar antara 4,68-52,40 mm/tahun dengan tren tertinggi terjadi pada Kabupaten Poso, sebagian Kabupaten Sigi, Tojo Una-una, Morowali Utara dan Morowali. Sedangkan tren terendah terjadi pada Kabupaten Banggai, Banggai Kepulauan dan Banggai Laut. Informasi ini dapat digunakan sebagai pertimbangan dalam kebijakan adaptasi dan mitigasi perubahan iklim di Provinsi Sulawesi Tengah. 


\section{Ucapan Terima Kasih}

Penulis mengucapkan terima kasih kepada pimpinan dan staf Stasiun Pemantau Atmosfer Global Lore Lindu Bariri atas dukungan, saran dan masukan serta sarana dalam melakukan kajian penelitian dan publikasi artikel ilmiah ini. Penulis juga berterimakasih kepada seluruh staff di Stasiun Meteorologi Syukuran Aminuddin Luwuk Banggai, Stasiun Meteorologi Kasiguncu Poso, Stasiun Meteorologi Sultan Bantilan ToliToli dan Stasiun Meteorologi Mutiara Palu atas ketersediaan data dalam kajian penelitian ini.

\section{DAFTAR PUSATAKA}

Aldrian, E., Susanto, R. D. (2003). Identification of three dominant rainfall regions within Indonesia and their relationship to sea surface temperature. International Journal of Climatology, 23(12), 1435-1452. doi:10.1002/joc.950

Alfiandy, S., Hutauruk, R. C. H., \& Permana, D. S. (2020). Peran dinamika laut dan topografi terhadap pola hujan tipe lokal di wilayah Kota Palu. Depik Jurnal IImu - IImu Perairan, Pesisir dan Perikanan, 9(2), 173183. doi:10.13170/depik.9.2.16106

Alfiandy, S., Permana, D. S., Nurjaman, A.W., Kurnia, W. G., Prastika, L., Panggabean, H., Soeharto, M., Wulandari, S., Setiawan, H., Hendrawan, A., Miranda. (2020a). Analisis Iklim Provinsi Sulawesi Tengah Berdasarkan Data Dari Alat Pemantau Cuaca Otomatis. Buletin GAW Bariri, 1(1), 1-11.

Apriana, Y., Susanti, E., Ramadhani, F., Surmaini, E. (2016). Analisis Dampak Perubahan Iklim terhadap Produksi Tanaman Pangan pada Lahan Kering dan Rancang Bangun Sistem Informasinya. Informatika Pertanian, 25(1), 69-80. doi: 10.21082/ip.v25n1.2016.p69-80

Dasanto, B. D., Boer, R., Pramudya, B., Suharnoto, Y. (2014). Evaluasi Curah Hujan TRMM Menggunakan Pendekatan Koreksi Bias Statistik. Jurnal Tanah Dan Iklim, 38(1), 15-24. doi: 10.21082/jti.v38n1.2014.15-24

Fitria, M. (2016). Validasi data curah hujan Global Satellite Mapping of Precipitation (GSMAP) pada tiga pola hujan di Indonesia. Skripsi, Institut Pertanian Bogor.

Fuentes-Franco, R., Coppola, E., Giorgi, F., Pavia, E. G., Diro, G. T., Graef, F. (2015). Inter-annual variability of precipitation over Southern Mexico and Central America and its relationship to sea surface temperature from a set of future projections from CMIP5 GCMs and RegCM4 CORDEX simulations. Climate Dynamics, 45(1), 425-440. doi:10.1007/s00382-014-2258-6

Gelaro, R., W. McCarty, M.J. Suárez, R. Todling, A. Molod, L. Takacs, C.A. Randles, A. Darmenov, M.G. Bosilovich, R. Reichle, K. Wargan, L. Coy, R. Cullather, C. Draper, S. Akella, V. Buchard, A. Conaty, A.M. da Silva, W. Gu, G. Kim, R. Koster, R. Lucchesi, D. Merkova, J.E. Nielsen, G. Partyka, S. Pawson, W. Putman, M. Rienecker, S.D. Schubert, M. Sienkiewicz, B. Zhao. (2017). The Modern-Era Retrospective Analysis for Research and Applications, Version 2 (MERRA-2). J. Climate, 30, 5419-5454. doi:10.1175/JCLID-16-0758.1

Hidayati, I. N., Suryanto, S. (2015). Pengaruh Perubahan Iklim Terhadap Produksi Pertanian Dan Strategi Adaptasi Pada Lahan Rawan Kekeringan. Jurnal Ekonomi \& Studi Pembangunan, 16(1), 42-52. doi: 10.18196/jesp.2015.0040.42-52

Hosang, P. R., Tatuh, J., Rogi, J. E. X. (2012). Analisis Dampak Perubahan Iklim terhadap Produksi Beras Provinsi Sulawesi Utara Tahun 2013-2030. Eugenia, 18(3). doi: 10.35791/eug.18.3.2012.4101

Mufti, F., Ismail, N., Umar, M. (2017). Trend Analysis of Extreme Rainfall From 19822013 and Projection From 2014-2050 in Banda Aceh and Meulaboh. Jurnal Natural, 17(2), 122. doi:10.24815/jn.v17i2.7012

Santoso, W. Y. (2015). Kebijakan Nasional Indonesia dalam Adaptasi dan Mitigasi Perubahan Iklim. Hasanuddin Law Review, 1(3), 371-390. doi: 10.20956/halrev.v1i3.116

Setiawan, O. (2012). Analisis variabilitas curah hujan dan suhu di Bali. Jurnal Analisis Kebijakan Kehutanan, 9(1), 66-79. doi: 10.20886/jakk.2012.9.1.66-79

Sudarma, I. M., As-syakur, A. R. (2018). Dampak perubahan iklim terhadap sektor pertanian di Provinsi Bali. SOCA: Jurnal Sosial Ekonomi Pertanian, 87-98.

Supari., Tangang, F., Juneng, L., Aldrian, E. (2017). Observed changes in extreme temperature and precipitation over Indonesia. International Journal of Climatology, 37(4), 1979-1997. doi: 10.1002/joc.4829

Surmaini, E., Runtunuwu, E., Las, I. (2015). Upaya sektor pertanian dalam menghadapi perubahan iklim. Jurnal Penelitian Dan Pengembangan Pertanian, 30(1), 1-7. doi: 10.21082/jp3.v30n1.2011.p1-7

Syaifullah, M. D. (2014). Validasi data TRMM terhadap data curah hujan aktual di tiga DAS di Indonesia. Jurnal Meteorologi Dan Geofisika, 15(2). doi: 10.31172/jmg.v15i2.180 